WSRC-RP-92-351

\title{
RESULTS OF THE AIR INLEAKAGE TEST DEMONSTRATED AT THE PHEF FOR THE SALT PROCESS CELL (U)
}

WSRC-KP $-92-351$

by $H$. B. Shah

Westinghouse Savannah River Company

DE93 003379

Savannah River Site

Aiken, South Carolina 29808

Other Authors:

R. A. Jacobs

This paper was prepared in connection with work done under Contract No. DE-AC09-89SR18035 with the U. S. Department of Energy. By acceptance of this paper, the publisher and/or recipient acknowledges the U.S. Government's right to retain a nonexclusive, royalty-free license in and to any copyright covering this paper, along with the right to reproduce and to authorize others to reproduce all or part of the copyrighted paper. 


\section{DISCLAIMER}

This report was prepared as an account of work sponsored by an agency of the United States Government. Neither the United States Government nor any agency thereof, nor any of their employees, makes any warranty, express or implied, or assumes any legal liability or responsibility for the accuracy, completeness, or usefulness of any information, apparatus, product, or process disclosed, or represents that its use would not infringe privately owned rights. Reference herein to any specific commercial product, process, or service by trade name, trademark, manufacturer, or otherwise does not necessarily constitute or imply its endorsement, recommendation, or favoring by the United States Government or any agency thereof. The views and opinions of authors expressed herein do not necessarily state or reflect those of the United States Government or any agency thereof.

This report has been reproduced directly from the best available copy.

Available to DOE and DOE contractors from the Office of Scientific and Technical Information, P.O. Box 62, Oak Ridge, TN 37831; prices available from (615) 576-8401, FTS 626-8401.

Available to the public from the National Technical Information Service, U.S. Department of Commerce, 5285 Port Royal Rd., Springfield, VA 22161. 
Keywords: DWPF, Salt Process Cell, Precipitate Hydrolysis, Air Inleakage

Retention: Permanent

$\begin{array}{lll}\text { CC: } & \text { J. T. } & \text { Carter, 704-1T } \\ & \text { L. F. Landon, 704-T } \\ & \text { S. R. Young, 704-1T } \\ \text { J. C. } & \text { Marek, 704-T } \\ \text { M. A. Baich, 704-T } \\ \text { R. E. Eibling, 704-T } \\ \text { D. P. Lambert, 704-1T } \\ \text { R. C. Edwards, 704-1T }\end{array}$

March 2, 1992

TO: $\quad$ E. W. Holtzscheiter, 773-A

FROM: H. B. Shah, 704-1T

R. A. Jacobs, 704-T

\section{RESULTS OF THE AIR INLEAKAGE TEST DEMONSTRATED AT THE PHEE FOB THE SALT RROCESS CEII (U)}

\section{SUMMARY}

Air leaks into the salt processing cells (SPC) vessels because they are maintained at a slight negative pressure with respect to the cell. The Process Operating Procedure (POP) 27-355-506 was written at DWPF to measure air inleakage of the PRET, PR, OE and OECT.

DWPF requested SRL to demonstrate the Air Inleakage Test at the PHEF. The purpose of implementing the test at the PHEF was to:

(1) Determine if the existing DWPF Process operating Procedure (POP) algorithum provides a reliable tool to conduct the test, and

(2) if the existing method proves to be inadequate, then develop a new method to conduct the test.

The existing POP did not perform satisfactorily during PHEF demonstrations. Although its failure was in part due to the small molecular difference between air and the PHEF inertant (nitrogen), the $\mathrm{POP}$ is not expected to be adequate even with $\mathrm{CO} 2$ as the inertant. Two tests were conducted at the PHEF using a new method [2] with promising results. The method and test results are summarized in this report.

Authorized Derivative Classifier
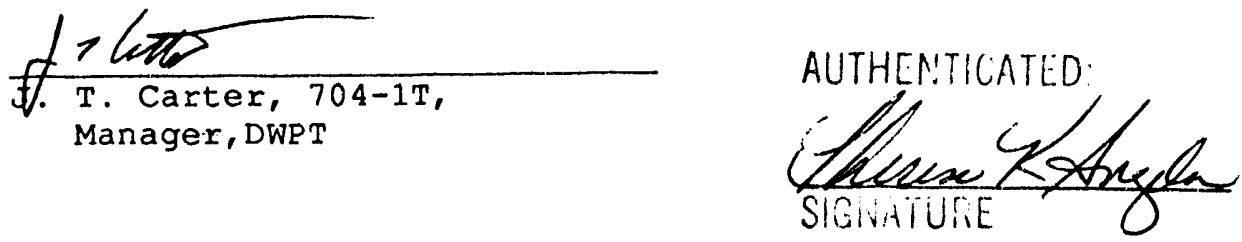

$\frac{3-10}{D A T E}-22$ 


\section{Bir Inleakage Test Using DWPE PQR:}

Test Algorithm

The test is done by performing a calculation to estimate the oxygen concentration in each of the four tanks in the SPC. These include the Precipitate Reactor (PR), the Precipitate Reactor Feed Tank (PRFT), the Organic Evaporator (OE), and the Organic Evaporator Condensate Tank (OECT).

Two oxygen analyzers monitor the combined exhaust stream of the above mentioned vessels and serve as the primary protection against the high oxygen concentrations. There are software and hardwire interlocks associated with the analyzers that will put the SPC in a safe mode.

This POP is more than an independent check against the Oxygen analysers. The POP calculates the 02 concentration in the individual vessels. This calculation is critical since it is possible to have 02 concentration above the MOC in a portion of the system vessels and below MOC at the SCVC exit. The most likely scenerio that would cause this discrepancy would be large inleakage into one vessel and low inleakage into the systems other vesels.

The main steps of the algorithum are summarized below. The algorithum

(1) Computes the average vessel $\mathrm{CO} 2$ purge flow and exhaust flow over average minutes.

(2) Calculates the density of the vapor in the vessel from the average $\mathrm{CO} 2$ purge and exhaust flow.

(3) Calculates the density of the vapor in the vessel on a benzene free basis.

(4) Calculates the approximate oxygen concentration in the vessel from the benzene free basis density of the vessel.

(5) When the oxygen concentration is less than the referenced maximum oxygen concentration allowed for the vessel, the test is considered complete.

\section{Test Results}

The test conducted at the PHEF measured the nitrogen purge at the PR inlet and the Vent Condenser vapor outlet and the oxygen at the VC exit. The Vent Condenser vapor exit flow was measured with a Kurz flow transmitter and oxygen was measured with a gas chromatograph. The DWPF POP test was inconclusive at PHEF because of the inertant nitrogen density being very close to air, the inability of the kurz transmitter to read accurately at the low flows and the small difference between flow values. 


\section{New Test Methed Developed at the PHEF:}

The new air inleakage test algorithm is described in reference [2]. It is assumed that the composition at the Kurz transmitter would not change due to change in the vacuum. This assumption relies on steps being performed quickly enough so that the composition does not change. The test outline for DWPF is described below. The test conducted at the PHEF facility is described in Attachment A [1].

Test Outline For DWPE

The method outlined below represents the steps to carry out tre testing of the new algorithm. Note that the meshod is generalized here. More detailed work is required to corduct the test for suggested vessels at DWPF.

The pressure meter should be zeroed before the test is conducted. Zero error is the deviation in the pressure transmitter at the readir.g of 0.0 inwc for the specified calibration range. If the transmitter can be zeroed then the zero error is removed. This deviation is incorporated in the algorithm as a correction facsor to calculate tre corrected flow. The deviation can be positive or negative.

It is very essential to characterize the air inleakage as a functicn of $\Delta \mathrm{P}$ to use in the final correction step. Please refer to reference [2] for more details. The flow through the points of leakage at tre PHEF is determined to be turbulent. The measured exponent for the $\Delta$ ? term at PHEF is 0.425 , which is slightly out of expected range [1]. It is believed that the low pressure drop at PHEF may be causing tre flow coefficient to vary considerably. This could have the considerable effect on the exponent.

Step 1

- Set the Precipitate Reactor (PR) at -2 inwc. (Referred as reference pressure. Reference pressure can be $-2,-3,-4$ inwc).

- Set $\mathrm{CO} 2$ purge flow to the PR at 2 scfm. ( This flow could be DWPF process standby flo\%.)

- Allow the system to reach steady-state, where, the oxygen Concentration would not change. (i.e it will take approximately two to three hours. This is to set up quiescent condition which is starting point for DWPF.)

- When the system comes to steady state, measure the following parameters.

Precipitate Reactor Pressure

Inlet $\mathrm{CO} 2$ purge flow to the PR

Flow at the PR exit

Precipitate Reactor temperature

Ambient temperature

(T1) inwe

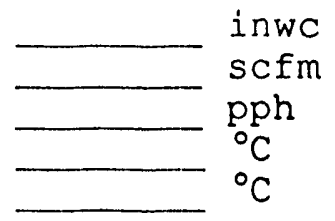


Ste: 2

- With the PR pressure at -2 inwc, increase the inlet CO2 purge by 2 scfm. Due to increase in the flow, the PR pressure will fluctuate. As soon as the PR pressure settles out, measure the following parameters:

Precipitate Reactor pressure Inlet $\mathrm{CO} 2$ purge flow to the $\mathrm{PR}$ Flow at the PR exit

inwe scfm

The flowmeter response to the change in flow is $\frac{\mathrm{F} 4-\mathrm{F} 2}{\mathrm{E} 3-\mathrm{F} 1^{*}\left(273+\mathrm{T} 1^{\circ} \mathrm{K} / 273^{\circ} \mathrm{K}\right)}=\mathrm{X} 1 \mathrm{lbs} / \mathrm{hr}$ per acfm

Step 3

- With the PR pressure at -2 inwc., decrease the inlet $\mathrm{CO} 2$ to $2 \mathrm{scfm}$. As soon as the PR pressure stabilizes, measure the following parameters. This step works as a meter calibration.

Precipitate Reactor Pressure Inlet $\mathrm{CO} 2$ purge flow to the PR Flow at the PR exit inwe scfm $\mathrm{pph}$

Note:

Step 3 is not required except to verify to see if things go back to step 1 . F2 of Step 1 should be the same as F6 of Step 3 .

Step 4

This step requires to change the process pressure to change the air inleakage into the system. Increase the PR pressure to -12 inwc with the inlet $\mathrm{CO} 2$ purge flow at $2 \mathrm{scfm}$. After the PR pressure stabilizes to -12 inwc., measure the following parameters.

Precipiate reactor pressure

Inlet $\mathrm{CO} 2$ purge flow to the $\mathrm{PR}$

Flow at the PR exit

inwe scfm

From step 3 and 4, calculate the difference in air inleakage caused by the increased vacuum.

$$
\frac{(F 8-F 6) 1 \mathrm{bs} / \mathrm{hr}}{\mathrm{x} 1 \mathrm{lbs} / \mathrm{hr} \text { per acfm }}=x 2 \mathrm{ft} \wedge 3 / \mathrm{min}
$$

The next step is to calculate the air inleakage at initial condition of -2 inwc. Assume turbulent flow which is proportional to the square root of the pressures. The exponent for the $\triangle \mathrm{P}$ term must be derived for the DWPF [2].

$$
\frac{\mathrm{x} 2 \mathrm{ft}^{\wedge} 3 / \mathrm{min}}{\sqrt{\mathrm{P} 4 / \mathrm{P} 1}-1}=\mathrm{x} 3 \mathrm{ft} \wedge 3 / \mathrm{min}
$$


Any error detected while zeroing the meter should be incorporated in the above equation for $P 4$ and $P 1$. Please refer attachment $A$ for more details.

Correcting back to standard conditions, the calculated air inleakage is

$\mathrm{x} 3 \mathrm{ft} \wedge 3 / \mathrm{min} \star \frac{273^{\circ} \mathrm{K}}{273+\mathrm{T} 1^{\circ} \mathrm{K}}=\mathrm{x} 4 \mathrm{scfm}$

and the calculated 02 concentration is

$$
\frac{21 \% \star x 4 \operatorname{scfm}}{X 4 \operatorname{scfm}+\mathrm{F} 1 \text { scfm }}=\div 02
$$

\section{TEST RESULTS:}

Two tests were conducted with the new algorithum at the PHEF. Test 1 and 2 were conducted at the reference pressure of -2 and -4 inwc respectively. Data of the tests are documented in Table 1 below. Please refer Attachment A for variable descriptions and steps of the test.

\section{Table 1:}

Step

1

2

3

$\hat{4}$

5
Measured

variables

P1, inwc

F1, pph

F2, pph

C1, vol\%

P2, inwc

F3, pph

F4, pph

C2, vol\%

P3, inwc

F5, pph

F6, pph

C3, vol\%

P4, inwC

F7, pph

F8, pph

C4, vol:

$P 5$, inwc

F9, pph

E10, pph

C5, vol\%
Test 1

Test 2

2.0

40.7

48.9

4.00

2.0

60.2

70.8

4.00

2.0

41.2

47.8

3.98

4.0

40.0

50.2

4.38

3.9

60.1

71.5

4.38

12.1

40.1

58.8

3.81

12.1

40.5

60.3

7.22
4.0

41.2

50 .?

4.49

12.0

41.1

55.6

4.60

12.0

40.9

54.7

6.19 
The =HEF test calculations are shown in Attachment $A$ and summarized in Table 2 below.

\section{TABLE 2:}

\begin{tabular}{|c|c|c|c|c|c|c|}
\hline $\begin{array}{l}\text { Measurd } A \\
02 \text { conc } \\
\& \text { wt (C1) }\end{array}$ & $\begin{array}{l}\text { Calcu. } \\
\text { Epred1, } \\
\text { pph }\end{array}$ & $\begin{array}{l}\text { Corre. Calc } \\
\text { Fpred2, } \\
\text { pph }\end{array}$ & $\begin{array}{l}\text { Calcu. } \\
\text { O2 Con; } \\
\text { \& (C6) }\end{array}$ & $\begin{array}{l}\text { Corre. E } \\
\text { Calcu. } \\
02, \text { of }^{\prime}(\mathrm{C})\end{array}$ & $\begin{array}{l}z \text { error } F \\
\text { in Calcu. } \\
02,8\end{array}$ & $\begin{array}{l}\text { \&error: } r^{G} \\
\text { Corr.Calc. } \\
02, \quad 8\end{array}$ \\
\hline 4.55 & 7.89 & 8.67 & 3.78 & 4.09 & -16.92 & -10.11 \\
\hline 4.96 & 8.78 & 9.29 & 4.18 & 4.38 & -15.72 & -11.69 \\
\hline
\end{tabular}

Wr.eะe,
A. Measured $\mathrm{O} 2$ concentration computed in weight $\frac{\circ}{0}$.
B. Calculated Air Flow (Exredi) based on the corrected air flow.
C. Corrected Calculated Air Flow (Fpred2) based on the transmitter zero error.
D. Calculated oxygen concentration, wto (C6) from Fpredl.
E. Corrected Calculated Oxygen Concentration wt: (C7) from Fred2
F. $\quad \frac{q}{0}$ error in Calculated oxygen Concentration (C6) compared to measured 02 concentration (C1).
G. $\quad \frac{q}{z}$ error in Corrected Calculated Oxygen Concentration (C7) compared to measured 02 concentration (C1).

\section{Conclusion:}

The method was tested at -2 and -4 inwc of reference pressure. Based on the two test results, it seems that the suggested method works. The procedure was mainly evaluated at $40 \mathrm{pph}$ of nitrogen purge to the PR. The Kurz flow transmitter failure recently, prevented to test the meirod at low purge rate (less than $40 \mathrm{pph}$ ). The flow through the poir.ts of leakage at the PHEF is determined to be turbulent. The measured exponent for the $\triangle \mathrm{P}$ term at $\mathrm{PHEF}$ is 0.425 , which is slightly ol: $=$ of expected range. Therefore, It is essential to characterize the aic inleakage as a function of $\triangle \mathrm{P}$ for $\mathrm{DWPF}$.

\section{References:}

1. H. B. Shah, LABORATORY NOTEBOOKS, DPSTN-4671 AND WSRC-NB-פJ-178.

2. R. A. Jacobs, "RESPONSE OF DWPF THERMAL FLOWMETERS TO COMEOSITION CHANGE- EFFECT ON O2 DETERMINATION IN SPC", Savannah River Site Document, WSRC-TR-92-0069, February 3,1992. 


\section{Attachment A}

The mothod and algorithm tested at PHEF are described below. In order to counter check the algorithm, the system was allowed to reach steady-state after a six fold increase in the vacuum. Note that this step is not required at DWPF. During the test at the PHEF,

(1) Organic Evaporator (OE) and Organic Evaporator Condenser Decanter (OECD) were valved out.

(2) The Precipitate Reactor (PR) vacuum breakers were valved out.

(3) All the level probe purges were shut off.

(4) The PR pressure transmitter was zeroed before the test. Step 1

- Precipitate Reactor (PR) was set at -2 inwc. (referred as reference pressure).

- The nitrogen purge flow to the PR was maintained at $40 \mathrm{pph}$.

- Air was bleed into the system such that the oxygen concentration at the Vent Condenser exit would be a minimum of $4 \%$.

- System was allowed to reach steady-state, where the Oxygen Concentration did not change. ( it took approximately two to three hours.)

- When the system reached steady state, following parameters were measured.

Precipitate Reactor Pressure Inlet $\mathrm{N} 2$ purge flow to the PR Flow at the vent condenser exit Oxygen concentration at VC exit Precipitate Reactor temperature

(P1)

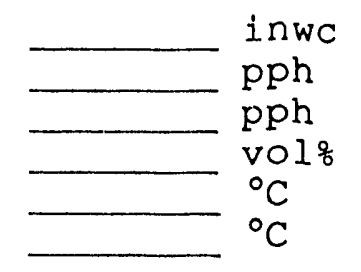

Step 2

- At the PR pressure of -2 inwc, increased the inlet nitrogen purge to $60 \mathrm{pph}$. After the PR pressure stabilized, following parameters were measured:

Precipitate Reactor pressure Inlet $N 2$ purge flow to the PR Flow at the vent condenser exit oxygen concentration at VC exit

inwc pph pph vol:

$S t \in \supseteq 3$

- With the PR pressure at -2 inwc., decreased the inlet nitrogen to $40 \mathrm{pph}$. After the PR pressure stabilized, following parameters were measured. 
Precipitate Reactor Pressure

(P3)

Inlet N2 purge flow to the PR

$(\mathrm{F} 5)$

Flow at the vent condenser exit (F6)

oxygen concentration at VC exit

(C3)

inwe

pph

pph

vol?

Step 4

- Increased the PR pressure to -12 inwc with the inlet nitrogen

purge flow at $40 \mathrm{pph}$. After the PR pressure stabilized to -12

inwc., following parameters were measured.

Precipiate reactor pressure

Inlet $\mathrm{N} 2$ purge flow to the PR

Flow at the vent condenser exit

(P4)

$(\mathrm{F} 7)$

oxygen concentration at VC exit

(C4)

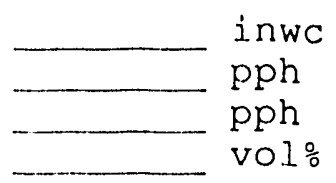

Step 5

- The system was allowed to arrive at stedy-state at -12 inwc. At stedy state, following parameters were measured.

Precipitate Reactor Pressure

Inlet $\mathrm{N} 2$ purge flow to the PR

Flow at the VC exit

(P5)

(F9)

(F10)

oxygen concentration at VC exit

Precipitate Reactor temperature

(C5)

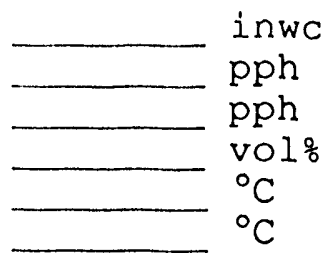

Ambient temperature

\section{CAICULATIONS:}

The computations below represent the Air Inleakage Test \#1 conducted at PHEF [1].

(1) Calculate air flow (X1) from Nitrogen purge to the PR a -2 inwC (P1) and $940 \mathrm{pph}$ (F1).

Oxygen Concentration $(C 1)=4.00 \%$ Vol $=4.5455$ \% weight

$$
\begin{aligned}
\mathrm{X} 1 & =\text { air flow in pph } \\
\frac{0.233 \times 1}{\mathrm{~F} 1+\mathrm{X} 1} & =0.045455 \\
\mathrm{X} 1 & =9.86 \mathrm{pph}
\end{aligned}
$$

Calculate air flow (X2) from Nitrogen purge to the PR e -12 inwC (P5) and $940 \mathrm{pph}$ (F9).

Oxygen Concentration $(C 5)=7.22 \%$ Vol $=8.1672 \%$ weight

$\mathrm{x} 2=\operatorname{air}$ flow in $\mathrm{pph}$ 


$$
\begin{aligned}
& \frac{0.233 \times 2}{F 9+x 2}=0.081672 \\
& x 2=21.86 \mathrm{pph}
\end{aligned}
$$

$\Delta$ Flow $=\times 2-X 1$

$$
=21.86-9.86=12.00 \mathrm{pph}
$$

(2) Calculate predicted Flow from difference in pressure.

$$
\begin{aligned}
\text { Fpred from } \Delta \text { Flow } & =\frac{(X 2-\times 1)}{(\mathrm{P} 5 / \mathrm{P} 1) 0.425-1} \\
& =\frac{12.0}{(12 / 2) 0.425-1} \\
& =8.28 \mathrm{pph}
\end{aligned}
$$

A 0.3 inch zero error of Pressure Transmitter was detected before the start up of the test.

$$
\begin{aligned}
\text { Corrected F Pred } & =\frac{(\mathrm{X} 2-\mathrm{X} 1)}{(\mathrm{P} 5 / \mathrm{P} 1)^{0.425}-1} \\
& =\frac{12.0}{(12.3 / 2.3)^{0.425-1}} \\
& =9.14 \mathrm{pph}
\end{aligned}
$$

(3) Calculate vapor density in the PR from change in the purge rate and the exhaust flow.

$$
\begin{aligned}
& \text { Volu.Purge } \mathrm{FR}\left(\Delta \mathrm{V}^{*}\right)=[(\mathrm{F} 3-\mathrm{F} 1) / \mathrm{N} 2 \mathrm{MW}] *(359 \mathrm{ft} \wedge 3 / 1 \mathrm{bmole}) *\left(\mathrm{~T} 2 / \mathrm{T} 1^{\circ} \mathrm{K}\right) \\
& =(60.2-40.7 / 28) * 359 * 298 / 273=273 \mathrm{ft}^{\wedge} 3 / \mathrm{h} \\
& \text { Where, } \quad \mathrm{T} 2=\mathrm{PR} \text { temperature, }{ }^{\circ} \mathrm{K} \\
& \text { Vapor density } \quad=\frac{(F 4-F 2)}{\Delta V} \\
& =70.8-48.9 / 273 \\
& =0.08022 \mathrm{lbs} / \mathrm{ft}^{\wedge} 3 \\
& =12.47 \mathrm{ft}^{\wedge} 3 / 1 \mathrm{bs}
\end{aligned}
$$

(4) Calculate corrected air flow based on the vapor density and air density.

$$
\begin{aligned}
\text { Volu. Air flowrate } & =(\text { F8 }-\mathrm{F} 2) * \text { Vapor density } \\
& =(58.8-48.9) * 12.47=123.45 \mathrm{ft} \wedge 3 / \mathrm{hr} \\
\text { Air density } & =\frac{\text { MWair* } 273}{359 *\left(\text { Ambient Temp. }+273^{\circ} \mathrm{K}\right)}
\end{aligned}
$$




$$
=0.07278 \mathrm{lbs} / \mathrm{ft}^{\wedge} 3
$$

Where,

$$
\begin{aligned}
\text { MW Air } & =29 \mathrm{Lb} / \text { Lbmole } \\
\text { Ambient Temp }{ }^{\circ} \mathrm{K} & =30{ }^{\circ} \mathrm{C} \\
\text { Corrected } \Delta \text { air flow } & =\text { (Volumetric air flowrate) (Air density) } \\
& =123.45 \star 0.07278 \\
& =8.98 \mathrm{pph}
\end{aligned}
$$

(5) Compute the Calculated Predicted Flow based on the corrected air flow.

$$
\begin{aligned}
\text { Calculated Flow, Fred1 } & =\frac{\text { Corrected } \Delta A_{\text {ir }}}{(\mathrm{P} 4 / \mathrm{P} 1) 0.425-1} \\
& =\frac{8.98}{(12 / 2) 0.425-1}=7.89 \mathrm{pph} \ldots \ldots \text { (a) }
\end{aligned}
$$

For 0.3 inwc zero error of pressure transmitter

Corrected Calculated

$$
\begin{aligned}
\text { Flow, Fred2 } & =\frac{\text { Corrected } \Delta \text { air }}{(\mathrm{P} 4 / \mathrm{P} 1)^{0.425-1}} \\
& =\frac{8.98}{(12.3 / 2.3)^{0.425-1}} \\
& =8.67 \mathrm{pph} \ldots
\end{aligned}
$$

(6) Compute the Calculated Oxygen Concentration based on the calculated predicted flow.

From equation a

Calculated Oxygen(C6)

$$
\begin{aligned}
& =\frac{0.233 * F_{\text {Pred } 1}}{\text { F1 }+F_{\text {Pred1 }}} \\
& =\frac{0.233 * 7.89}{40.7+7.89} \\
& =3.78 \% \mathrm{~W}
\end{aligned}
$$

From equation $\mathrm{b}$

Corrected Calculated (C7)

$$
=\frac{0.233 * F_{\text {Pred2 }}}{F 1+F_{\text {Pred2 }}}
$$

oxygen

$$
\begin{aligned}
& =\frac{0.233 * 8.67}{40.7+8.67} \\
& =4.09 \% \mathrm{~W}
\end{aligned}
$$


E. W. Holtzscheiter

11

WSRC-RP $-92-351$

(7) Actual Oxygen Concentration (C1) Measured @ VC exit $=4.55 \% \mathrm{~W}$ serror in Calculated oxygen

$$
\begin{aligned}
& =+/-\frac{(C 1-C 6)}{C 1} * 100 \\
& =(4.55-3.78) / 4.55 * 100 \\
& =-16.92 \%
\end{aligned}
$$

Ferror in Corrected calculated

$$
\begin{aligned}
& =+1-\frac{(C 1-C 7)}{C 1} * 100 \\
& =(4.55-4.09) / 4.55 * 100 \\
& =-10.11 \%
\end{aligned}
$$




\section{DISCLAIMER}

This report was prepared as an account of work sponsored by an agency of the United States Government. Neither the United States Government nor any agency thereof, nor any of their employees, makes any warranty, express or implied, or assumes any legal liability or responsibility for the accuracy, completeness, or usefulness of any information, apparatus, product, or process disclosed, or represents that its use would not infringe privately owned rights. Reference herein to any specific commercial product, process, or service by trade name, trademark, manufacturer, or otherwise does not necessarily constitute or imply its endorsement, recommendation, or favoring by the United States Government or any agency thereof. The views and opinions of authors expressed herein do not necessarily state or reflect those of the United States Government or any agency thereof.

This report has been reproduced directly from the best available copy.

Available to DOE and DOE contractors from the Office of Scientific and Technical Information, P.O. Box 62, Oak Ridge, TN 37831; prices available from (615) 576-8401, FTS 626-8401.

Available to the public from the National Technical Information Service, U.S. Department of Commerce, 5285 Port Royal Rd., Springfield, VA 22161. 

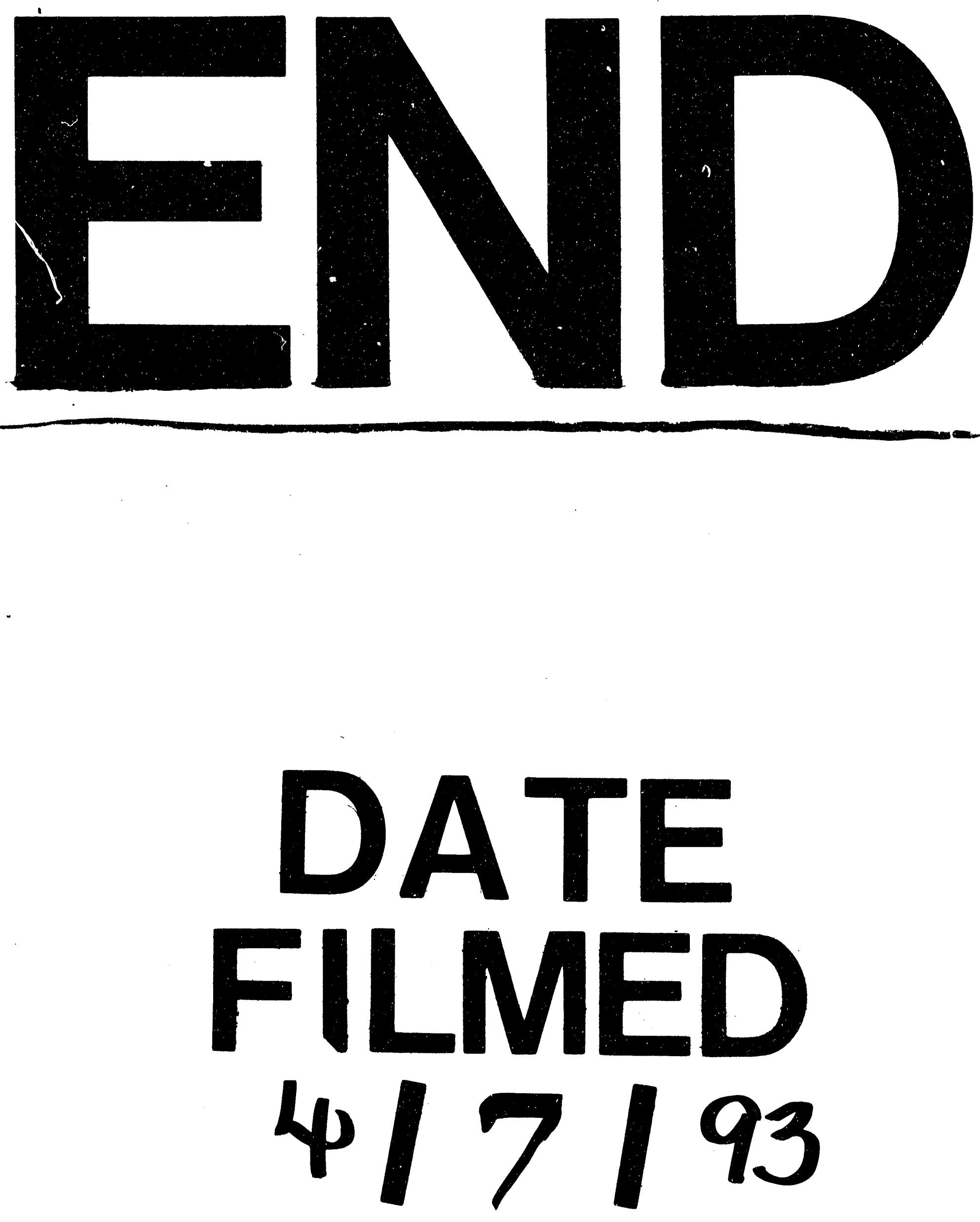


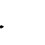

